\title{
Media Permainan Edukatif Tema Tanaman Sub Tema Sayur dan Buah untuk Anak Usia Dini
}

\author{
Kompiang Sari1 ${ }^{*}$, I Wayan Sujana ${ }^{2}$ \\ 1,2 Pendidikan Dasar, Universitas Pendidikan Ganesha, Singaraja, Indonesia
}

\section{ART I CLE I N F O}

Received 27 January 2021

Revised 15 February 2021

Accepted 01 April 2021

Available online 25 April 2021

Kata Kunci:

Media, Permainan Edukatif

Tema Tanaman

\section{Keywords:}

Media, Educational Games, Plant Theme

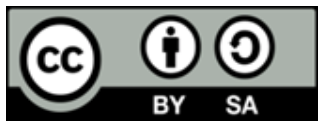

This is an open access article under the CC BY-SA license.

Copyright $($ C Universitas Pendidikan Ganesha. All rights reserved.
Article history:

\begin{abstract}
A B S T R A K
Pada pembelajaran tema tanaman sub tema sayur dan buah, anak usia dini tidak dapat menyerap dengan baik materi yang disampaikan guru dikarenakan kurang inovatifnya media yang digunakan, selain itu guru mengalami keterbatasan dalam mengembangkan media permainan edukatif dengan berbantuan teknologi untuk anak usia dini. Tujuan dari penelitian ini untuk mendeskripsikan rancang bangun media permainan edukatif dan mendeskripsikan kelayakan media permainan edukatif tema tanaman sub tema sayur dan buah, menurut review para ahli dan uji coba perorangan. Subjek penelitian ini terdiri dari tiga orang anak usia dini. Metode pengumpulan data yang digunakan adalah metode non tes dengan instrumen berupa angket/kuesioner. Penelitian ini menggunakan metode analisis deskriptif kualitatif dan analisis deskriptif kuantitatif. Model ADDIE dijadikan sebagai acuan dalam pengembangan media ini. Hasil uji validitas media permainan edukatif dari ahli isi pembelajaran, ahli desain pembelajaran, dan ahli media pembelajaran memperoleh rata-rata skor $94,46 \%$ termasuk kualifikasi sangat baik dan dari uji coba perorangan yaitu $96,67 \%$ dengan kualifikasi sangat baik. Sehingga dapat disimpulkan bahwa media permainan edukatif tema tanaman sub tema sayur dan buah layak digunakan untuk anak usia dini. Implikasi hasil penelitian ini yaitu media permainan edukatif dapat memberikan kesempatan pada anak untuk mengenal berbagai macam sayur dan buah dengan cara bermain, sehingga mampu menarik perhatian anak, membantu mengenalkan keaksaraan awal (bahasa), menstimulasi aspek kognitif anak dan meningkatkan minat belajar anak.
\end{abstract}

\section{A B S T R A C T}

In learning the theme of plants, the sub-theme of vegetables and fruit, early childhood cannot absorb the material presented by the teacher due to the lack of innovative media used, besides that the teacher has limitations in developing educational game media with the help of technology for early childhood. The purpose of this study is to describe the design of educational game media and to describe the feasibility of educational game media with the theme of plants, sub-themes of vegetables and fruit, according to expert reviews and individual trials. The subjects of this study consisted of three early childhood children. The data collection method used is a non-test method with an instrument in the form of a questionnaire/questionnaire. This research uses qualitative descriptive analysis method and quantitative descriptive analysis. The ADDIE model is used as a reference in the development of this media. The results of the validity test of educational game media from learning content experts, learning design experts, and learning media experts obtained an average score of $94.46 \%$ including very good qualifications and from individual trials, namely $96.67 \%$ with very good qualifications. So it can be concluded that the educational game media with the theme of vegetables and fruit sub-theme is suitable for use for early childhood. The implication of the results of this study is that educational game media can provide opportunities for children to get to know various kinds of vegetables and fruits by playing, so as to attract children's attention, help introduce early literacy (language), stimulate children's cognitive aspects and increase children's interest in learning.

Copyright (c) Universitas Pendidikan Ganesha. All rights reserved 


\section{Pendahuluan}

Dunia anak adalah dunia bermain, artinya selama rentang pertumbuhan dan perkembangannya selalu melakukan berbagai aktivitas dengan diselingi bermain. Bermain dijadikan sarana penting bagi anak, karena bermain dapat mengembangkan aspek-aspek perkembangan anak, dan anak akan lebih percaya diri, memiliki rasa nyaman, serta memiliki konsep diri yang positif (Fadlillah, 2019; Hairiyah \& Mukhlis, 2019). Bermain dapat memberikan kesempatan pada anak untuk memahami dunia, mengendalikan emosi, dan mengembangkan imajinasinya sehingga anak aktif membangun pengetahuannya (Amiran, 2016; Holis, 2017). Saat melakukan aktivitas bermain, anak tentunya membutuhkan sebuah permainan yang mengandung unsur atau nilai edukatif (pendidikan). Permainan yang bersifat mendidik di TK disebut dengan permainan edukatif. Permainan dapat dikategorikan sebagai permainan edukatif, jika permainan tersebut bisa dianalisis dari manfaat penggunanya (Aprilianto \& Mariana, 2018; Saputra, 2019). Permainan edukatif artinya permainan yang dikemas untuk merangsang daya pikir anak termasuk meningkatkan konsentrasi dan memecahkan masalah (Sudiatmika, Cahyawan, \& Buana, 2014; Rahman \& Tresnawati, 2016). Manfaatnya yaitu untuk meningkatkan kemampuan berbahasa, merangsang pemikiran, meningkatkan motivasi serta bergaul dengan lingkungannya (Putra, 2016; Lestari, Hadi, \& Mushafanah, 2019). Permainan edukatif tidak selalu identik dengan bahan daur ulang, tetapi permainan edukatif dapat dikembangkan dengan canggih dan modern sesuai dengan perkembangan zaman. Permainan edukatif semakin canggih memiliki keunggulan yaitu sebagai media pembelajaran karena prosesnya yang mudah, dapat dimainkan secara berulang-ulang, dan menyenangkan (Satria \& Rusda, 2017; Harjanta \& Herlambang, 2018). Di TK, permainan edukatif dapat dikemas sesuai dengan tema pembelajaran, seperti tema tanaman sub tema sayur dan buah.

Tema tanaman sub tema sayur dan buah merupakan salah satu tema pembelajaran yang diajarkan pada anak kelompok B semester satu di TK yang dapat membantu anak untuk mengetahui manfaat sayur dan buah, mengetahui dan menyebutkan nama-nama sayur dan buah, dan mengetahui keragaman warna yang terdapat pada sayur dan buah, sehingga dapat menstimulasi aspek perkembangan anak, diantaranya yaitu aspek kognitif dan bahasa. Kemampuan kognitif anak merupakan kemampuan komprehensif yang berkaitan dengan kemampuan menalar atau mengingat, memecahkan masalah dari berbagai obyek, serta kemampuan dalam mengenal warna (Norlaila, 2015; Bujuri, 2018). Sedangkan kemampuan bahasa anak usia 5-6 tahun memiliki karakteristik yaitu mampu mengucapkan kalimat panjang, mampu menjadi pendengar yang baik, dapat berpartisipasi dalam suatu percakapan, dan mempunyai perbendaharaan kata yang cukup baik (Hayati, Cholimah, \& Christianti, 2017; Hemah, Sayekti, \& Atikah, 2018). Permasalahan dari penelitian terdahulu yaitu saat mengenal nama sayuran dan buahbuahan, anak cenderung malas belajar karena bahan ajar yang kurang menarik dan metode digunakan masih bersifat konvensional, seperti guru mengajar dengan cara menunjuk gambar obyek dan memberitahu nama obyek tersebut sehingga membuat rasa ingin tahu anak berkurang (Ayuni Kaffah et al., 2020). Adapun juga permasalahan penelitian terdahulu yakni anak belum mampu dalam mengelompokkan benda berdasarkan bentuk, jenis, warna, dan ukuran, karena tidak adanya permainan edukatif yang dapat menstimulasi aspek perkembangan anak (Nurhayati, 2015).

Berdasarkan hasil observasi dan wawancara dengan guru di TK Widya Santhi Denpasar, diperoleh informasi bahwa terdapat permasalahan yang hampir sama dengan permasalahan penelitian terdahulu tersebut, yaitu permasalahannya pada saat pembelajaran tema tanaman sub tema sayur dan buah, anak kelompok B tidak dapat menyerap dengan baik materi yang disampaikan oleh guru. Hal itu disebabkan karena masih kurang inovatifnya media pembelajaran yang digunakan, seperti hanya menggunakan buku paket atau buku majalah serta menggunakan kartu bergambar sayur atau buah. Selain itu guru mengalami keterbatasan dalam mengembangkan media permainan edukatif khususnya tema tanaman sub tema sayur dan buah berbantuan teknologi yang kreatif dan menarik yang mampu menstimulasi aspek perkembangan anak, khususnya aspek kognitif dan bahasa.

Solusi dari permasalahan tersebut yaitu dikembangkannya media permainan edukatif tema tanaman sub tema sayur dan buah untuk anak kelompok B TK Widya Santhi Denpasar dengan berbantuan teknologi yang menarik dan mampu menstimulasi aspek kognitif dan aspek bahasa anak. Hal ini karena dengan memanfaatkan perkembangan teknologi dapat membantu para penggiat dalam mengembangkan berbagai macam media pembelajaran yang dapat memberikan pengetahuan dengan cara menyenangkan (Ramdani, Kurniadi, \& Septiana, 2019; Firmadani, 2020). Selain itu perkembangan teknologi yang canggih tentunya dapat membantu aktivitas dalam sistem belajar mengajar untuk mencapai tujuan pendidikan, serta berdampak pada kemudahan memperoleh informasi dan pengembangan media pembelajaran (Mubaraq, Kurniawan, \& Saleh, 2018; Tafonao, 2018; Erwin \& Syukur, 2019). Perkembangan teknologi saat ini juga mampu memberikan lima unsur lebih banyak dibandingkan metode konvensional yaitu adanya suara atau musik, animasi, teks, gambar, dan video, sehingga informasi yang diberikan kepada anak dapat disampaikan lebih banyak dan dapat membantu anak untuk belajar sendiri di rumah. 
Dasar pertimbangan pemilihan media permainan edukatif sayur dan buah yaitu permainan edukatif ini sangat menarik untuk dikembangkan. Tujuan media permainan edukatif sayur dan buah yang dikembangkan ini adalah untuk mengatasi masalah pembelajaran dalam meningkatkan minat belajar, membantu mengenalkan keaksaraan awal (aspek bahasa), menstimulasi aspek perkembangan kognitif anak dalam proses belajar, dan memberikan kesempatan pada anak untuk mengenal berbagai macam sayur dan buah dengan cara bermain. Media permainan edukatif tema tanaman sub tema sayur dan buah yang dikembangkan merupakan sebuah permainan yang dikemas dengan menggunakan teknologi berbasis android, sehingga permainan edukatif ini dapat dimainkan oleh anak kapan saja dan dimana saja. Permainan edukatif ini terdapat pengenalan nama-nama dari berbagai macam sayur dan buah dengan menggunakan tiga bahasa yaitu Bahasa Indonesia, Bahasa Inggris, dan Bahasa Bali. Penggunaan bahasa Indonesia dalam permainan edukatif ini mengingat bahasa Indonesia adalah bahasa yang sering dipakai dalam melakukan komunikasi sehari-hari oleh anak, sedangkan bahasa Inggris adalah bahasa Internasional yang diberlakukan di seluruh Negara, serta bahasa Bali adalah bahasa identitas atau warisan dari orang Bali yang penting diajarkan pada anak usia dini, mengingat anak usia dini sebagai penerus bangsa. Penelitian ini bertujuan untuk mendeskripsikan rancang bangun media permainan edukatif tema tanaman sub tema sayur dan buah dan untuk mendeskripsikan kelayakan media permainan edukatif tema tanaman sub tema sayur dan buah untuk anak kelompok B TK Widya Santhi Denpasar, menurut review para ahli dan uji coba perorangan.

\section{Metode}

Penelitian pengembangan ini menggunakan model penelitian pengembangan ADDIE. Model ADDIE merupakan model desain instruksional yang membangun materi maupun produk berdasarkan kinerja yang dapat digunakan untuk berbagai macam bentuk pengembangan produk seperti model, strategi pembelajaran, metode pembelajaran, media pembelajaran, dan bahan ajar (Rohaeni, 2020; Soesilo \& Munthe, 2020). Dasar pertimbangan pemilihan model ADDIE dalam penelitian pengembangan ini bahwa model penelitian ADDIE mudah dipahami karena terdapat langkah-langkah kegiatan yang terstruktur, sehingga memudahkan dalam menghasilkan atau mengembangkan sebuah produk yang efektif sesuai dengan kebutuhan dan karakteristik anak dalam proses pembelajaran. Model ADDIE terdiri dari lima tahapan, yaitu analisis (analysis), desain (design), pengembangan (development), implementasi (implementation), dan evaluasi (evaluation) (Isya', 2017).

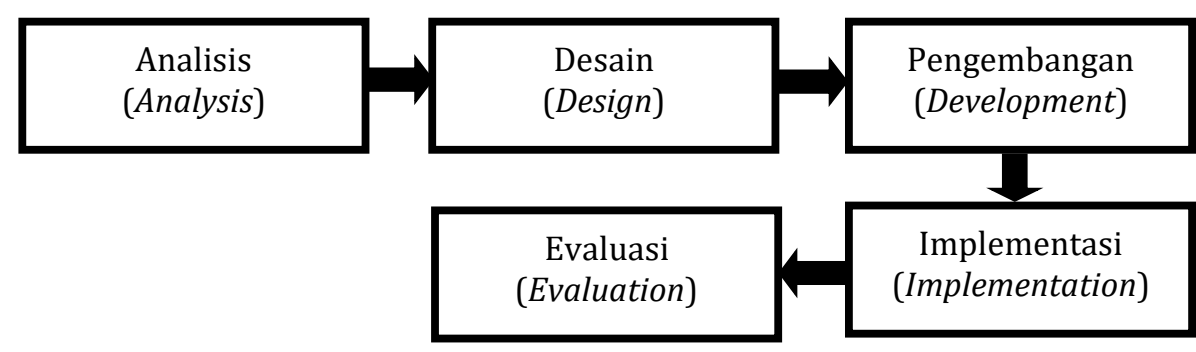

Gambar 1. Langkah-Langkah Model Pengembangan ADDIE

Sumber: (Sugiyono, 2015)

Tahap analisis (analysis) terdiri dari tiga tahap, diantaranya: analisis kesenjangan kinerja (permasalahan yang ada) yang bertujuan untuk mengklasifikasikan sebuah permasalahan yang terjadi dalam proses pembelajaran, analisis kebutuhan yang bertujuan untuk menentukan sebuah produk media pembelajaran sesuai dengan permasalahan yang ada di TK, dan analisis kurikulum yang berguna untuk menganalisis Kompetensi Dasar (KD) dan indikator tema pembelajaran (tema tanaman) di TK Widya Santhi Denpasar. Tahap desain (design) hal yang dilakukan yaitu menentukan alat yang digunakan, merancang flowchart dan storyboard untuk memudahkan pembuatan media, dan mendesain komponen media. Tahap pengembangan (development) yaitu mengembangkan media pembelajaran sesuai dengan rancangan pada tahap desain. Tahap implementasi (implementation) yaitu diimplementasikannya media pembelajaran yang ditujukan kepada para ahli dan uji coba produk, namun dikarenakan saat ini masih dalam kondisi pandemi covid-19 yang mengakibatkan anak belajar dari rumah secara daring sehingga penelitian ini hanya sampai tahap uji coba perorangan. Tahap evaluasi yaitu menilai produk media pembelajaran yang dikembangkan dan dilakukannya revisi akhir jika diperlukan.

Subjek uji coba pada tahap review para ahli yaitu terdiri dari satu orang ahli isi pembelajaran, satu orang ahli desain pembelajaran, dan satu orang ahli media pembelajaran. Subjek uji coba pada tahap uji 
coba perorangan terdiri dari 3 orang anak kelompok B TK Widya Santhi Denpasar yang berdasarkan pada tingkat pencapaian perkembangan anak dengan kriteria satu orang anak Mulai Berkembang (MB), satu orang anak Berkembang Sesuai Harapan (BSH), dan satu orang anak Berkembang Sangat Baik (BSB).

Metode pengumpulan data yang digunakan adalah metode non tes yang terdiri dari metode observasi, metode wawancara, dan angket atau kuesioner. Metode dan teknik analisis data yang digunakan dalam penelitian pengembangan ini yaitu analisis deskriptif kualitatif dan analisis deskriptif kuantitatif. Data kualitatif diperoleh berdasarkan masukan dan saran dari ahli isi pembelajaran, ahli desain pembelajaran, dan ahli media pembelajaran. Masukan dan saran tersebut dapat digunakan sebagai acuan dalam merevisi produk. Sedangkan data kuantitatif diperoleh dari hasil angket atau kuesioner dari ahli isi pembelajaran, ahli desain pembelajaran, ahli media pembelajaran, dan uji coba perorangan. Adapun kisi-kisi instrumen angket atau kuesioner yang digunakan untuk memperoleh informasi atau data dari uji validitas dan uji coba perorangan pada Tabel 1,2,3 dan 4.

Tabel 1. Kisi-Kisi Instrumen Ahli Isi Pembelajaran

\begin{tabular}{|c|c|c|c|}
\hline No & Aspek & Indikator & Jumlah Butir \\
\hline 1. & Kurikulum & $\begin{array}{l}\text { Kesesuaian media dengan Kompetensi Dasar (KD), Indikator, } \\
\text { dan Tujuan Pembelajaran }\end{array}$ & 1 \\
\hline 2. & Materi & $\begin{array}{l}\text { Kesesuaian materi pada media permainan edukatif } \\
\text { Kemenarikan materi pada setiap sesi dalam media permainan } \\
\text { edukatif }\end{array}$ & 9 \\
\hline & & Ketepatan penyajian materi dalam media & \\
\hline 3. & Tampilan & Kesesuaian gambar dengan materi & 1 \\
\hline \multirow[t]{2}{*}{4.} & Bahasa & Kejelasan penggunaan bahasa & 2 \\
\hline & & Jumlah Butir & 13 \\
\hline
\end{tabular}

Sumber Dimodifikasi: (Hasanah, 2020)

Tabel 2. Kisi-Kisi Instrumen Ahli Desain Pembelajaran

\begin{tabular}{|c|c|c|c|}
\hline No & Aspek & Indikator & Jumlah Butir \\
\hline 1. & Kurikulum & $\begin{array}{l}\text { Kesesuaian Kompetensi Dasar (KD), Indikator, dan Tujuan } \\
\text { Pembelajaran }\end{array}$ & 1 \\
\hline 2. & Materi & $\begin{array}{l}\text { Cakupan materi pada media } \\
\text { Kesesuaian materi pada media } \\
\text { Ketepatan materi pada media }\end{array}$ & 3 \\
\hline 3. & Penyajian & $\begin{array}{l}\text { Kesesuaian gambar dengan sub tema pembelajaran } \\
\text { Kemenarikan gambar dan tulisan pada media } \\
\text { Kejelasan tombol navigasi }\end{array}$ & 3 \\
\hline 4. & Bahasa & $\begin{array}{l}\text { Kejelasan penggunaan bahasa } \\
\text { Menggunakan nama-nama sayur dan buah yang mudah ditemui } \\
\text { anak }\end{array}$ & 2 \\
\hline 5. & Pemakaian & Kemudahan penggunaan media & 1 \\
\hline & & Jumlah Butir & 10 \\
\hline
\end{tabular}

Sumber Dimodifikasi: (Mardhotillah, 2019)

Tabel 3. Kisi-Kisi Instrumen Ahli Media Pembelajaran

\begin{tabular}{cclc}
\hline No & \multicolumn{1}{c}{ Aspek } & \multicolumn{1}{c}{ Indikator } & \multicolumn{1}{c}{ Jumlah Butir } \\
\hline 1. & Fisik & $\begin{array}{l}\text { Keamanan bahan yang digunakan } \\
\text { Keawetan bahan } \\
\text { Kemenarikan desain kemasan media } \\
\text { Kejelasan gambar dalam media }\end{array}$ & 3 \\
2. & Gambar & $\begin{array}{l}\text { Kesesuaian gambar dengan tema dan sub tema pembelajaran di } \\
\text { Taman Kanak-Kanak }\end{array}$ & 2 \\
3. & Audio & $\begin{array}{l}\text { Kejelasan suara atau music } \\
\text { Kesesuaian warna dengan karakteristik anak kelompok B } \\
\text { Taman Kanak-Kanak }\end{array}$ & 1 \\
4. & Warna & $\begin{array}{l}\text { Kesesuaian komposisi warna, gambar, dan tulisan } \\
\text { Kesesuaian ukuran tulisan }\end{array}$ & 2 \\
Kesesuaian jenis font yang digunakan & Tulisan & & 4 \\
\hline
\end{tabular}




\begin{tabular}{|c|c|c|c|}
\hline No & Aspek & Indikator & Jumlah Butir \\
\hline \multirow{8}{*}{6.} & \multirow{7}{*}{ Pemakaian } & Kejelasan tulisan judul media & \multirow{7}{*}{3} \\
\hline & & Kejelasan warna tulisan pada media & \\
\hline & & Kesesuaian media dengan karakteristik anak kelompok B & \\
\hline & & Taman Kanak-Kanak & \\
\hline & & Kepraktisan media (mudah dibawa dan digunakan kapan saja & \\
\hline & & dan dimana saja) & \\
\hline & & Ketepatan media dalam menstimulasi kemampuan anak & \\
\hline & & Jumlah Butir & 15 \\
\hline
\end{tabular}

Tabel 4. Kisi-Kisi Instrumen Uji Perorangan

\begin{tabular}{clc}
\hline No & \multicolumn{1}{c}{ Indikator } & Jumlah Butir \\
\hline 1. & Kemenarikan warna pada media & 1 \\
2. & Kemenarikan gambar pada media & 1 \\
3. & Kejelasan gambar media & 1 \\
4. & Kejelasan suara dalam pemberian petunjuk & 1 \\
5. & Kemenarikan musik dan lagu pada media & 1 \\
6. & Kemudahan memainkan media & 1 \\
7. & Kemenarikan pada setiap sesi dalam media permainan edukatif & 4 \\
\hline & \multicolumn{1}{c}{ Jumlah Butir } & $\mathbf{1 0}$ \\
\hline
\end{tabular}

Sumber Dimodifikasi:(Maslich, 2016)

\section{Hasil dan Pembahasan}

Produk yang dihasilkan dalam penelitian pengembangan ini berupa media permainan edukatif tema tanaman sub tema sayur dan buah yang dikemas dengan menggunakan teknologi berbasis android, sehingga dapat dimainkan oleh anak kapan saja dan dimana saja. Rancang bangun pengembangan media permainan edukatif ini telah dilakukan sesuai dengan model pengembangan ADDIE yang terdiri dari lima tahapan, diantaranya tahap analisis (analysis), tahap desain (design), tahap pengembangan (development), tahap implementasi (implementation), dan tahap evaluasi (evaluation). Tahap analisis terdiri dari tiga tahap, diantaranya yaitu analisis kesenjangan kinerja (permasalahan yang ada), yang berguna untuk mengetahui permasalahan yang terjadi dalam proses pembelajaran dan mencari tahu penyebabnya. Hasil analisis ini diperoleh dari informasi melalui hasil observasi dan wawancara dengan guru di TK Widya Santhi Denpasar, bahwa saat pembelajaran tema tanaman sub tema sayur dan buah, anak kelompok B tidak dapat menyerap dengan baik materi yang disampaikan oleh guru, karena masih kurang inovatifnya media pembelajaran yang digunakan, seperti hanya menggunakan buku paket atau buku majalah serta kartu bergambar sayur dan buah. Selain itu kendala yang dihadapi oleh guru yaitu keterbatasan dalam mengembangkan media permainan edukatif khususnya tema tanaman sub tema sayur dan buah berbantuan teknologi yang kreatif, menarik, dan mampu menstimulasi aspek perkembangan anak, khususnya aspek kognitif dan bahasa. Analisis kebutuhan yang berguna untuk mengetahui dan menentukan produk media pembelajaran sesuai dengan kebutuhan dan karakteristik anak. Menanggapi situasi kesenjangan kinerja (permasalahan yang ada) di TK Widya Santhi Denpasar tersebut, maka dibutuhkannya sebuah produk pengembangan media permainan edukatif tema tanaman sub tema sayur dan buah untuk anak kelompok B di TK Widya Santhi Denpasar yang dikemas dengan menggunakan teknologi berbasis android yang kreatif, menarik, dan mampu menstimulasi aspek perkembangan anak, khususnya yaitu aspek kognitif dan bahasa. Analisis kurikulum, pada tahap ini hal yang dilakukan yaitu mengidentifikasi Kompetensi Dasar (KD) dan indikator pembelajaran.

Tahap desain yang dilakukan yaitu merancang media permainan edukatif tema tanaman sub tema sayur dan buah yang terdiri dari pembuatan flowchart, merancang storyboard guna memudahkan proses pembuatan media, dan mendesain komponen media permainan edukatif dengan menggunakan software Unity dan Microsoft Visual Studio. Selain itu pada tahap ini, desain media permainan edukatif menggunakan jenis huruf Oswald bold $S D F$ untuk tulisan disetiap menu dengan ukuran font 50 point dan Roboto Bold untuk tulisan skor dengan ukuran font 100 point. Tahap pengembangan hal yang dilakukan yaitu dimulai dari rancangan desain yang berbentuk flowchart dan storyboard yang dikembangkan agar menjadi ke bentuk asli atau nyata, mencari sumber-sumber yang relevan atau referensi sesuai dengan tema yang digunakan yaitu tema tanaman sub tema sayur dan buah, menentukan gambar-gambar sayuran dan buah-buahan, pengaturan layout, background, dan pengisian suara. Kemudian seluruh komponen tersebut dikembangkan dan disusun menjadi satu sehingga menghasilkan sebuah media permainan 
edukatif tema tanaman sub tema sayur dan buah yang siap digunakan dalam proses pembelajaran di Taman Kanak-Kanak.

Tahap implementasi yaitu mengimplementasikan media permainan edukatif yang ditujukan kepada para ahli yang terdiri dari ahli isi pembelajaran, ahli desain pembelajaran, dan ahli media pembelajaran. Media permainan edukatif ini juga diterapkan kepada anak kelompok B TK Widya Santhi Denpasar untuk mengetahui respon anak dari segi kemenarikan dan segi kelayakan. Implementasi ini dilakukan dengan uji coba produk. Namun karena terkendala situasi pandemi covid-19 yang mengakibatkan anak belajar dari rumah secara daring, sehingga penelitian pengembangan ini hanya sampai pada tahap uji coba perorangan yang melibatkan tiga orang anak kelompok B TK Widya Santhi Denpasar yang berdasarkan pada tingkat pencapaian perkembangan anak dengan kriteria satu orang anak Mulai Berkembang (MB), satu orang anak Berkembang Sesuai Harapan (BSH), dan satu orang anak Berkembang Sangat Baik (BSB).

Tahap evaluasi yaitu dilakukannya evaluasi dari data yang telah terkumpul pada tahap implementasi. Evaluasi berguna untuk mengetahui apakah produk yang dikembangkan sudah valid atau layak untuk diaplikasikan dalam pembelajaran. Hal yang dinilai yaitu produk pengembangan media permainan edukatif tema tanaman sub tema sayur dan buah yang mencakup validasi dari uji para ahli yang terdiri dari uji ahli isi pembelajaran, uji ahli desain pembelajaran, dan uji ahli media pembelajaran, serta dilakukan uji coba perorangan oleh tiga orang anak kelompok B TK Widya Santhi Denpasar. Selain itu dilakukannya revisi akhir terhadap produk media permainan edukatif yang dikembangkan berdasarkan saran, masukan, maupun komentar dari uji para ahli dan uji coba perorangan, sehingga media yang dikembangkan menjadi lebih baik dan layak digunakan pada proses pembelajaran di TK. Hasil analisis validitas media permainan edukatif tema tanaman sub tema sayur dan buah ini dijabarkan menurut uji para ahli dan uji coba produk yang terdiri dari uji ahli isi pembelajaran, uji ahli desain pembelajaran, uji ahli media pembelajaran, dan uji coba perorangan. Keempat data tersebut dijelaskan secara berurutan sesuai dengan hasil yang diperoleh dari masing-masing tahapan uji coba, yaitu pada Tabel 5.

Tabel 5. Persentase Hasil Validitas Pengembangan Media Permainan Edukatif

\begin{tabular}{clcc}
\hline No. & \multicolumn{1}{c}{ Subjek Uji Coba } & Hasil Validitas (\%) & Kualifikasi Persentase \\
\hline 1. & Uji Ahli Isi Pembelajaran & 94,23 & Sangat Baik \\
2. & Uji Ahli Desain Pembelajaran & 92,5 & Sangat Baik \\
3. & Uji Ahli Media Pembelajaran & 96,67 & Sangat Baik \\
4. & Uji Coba Perorangan & 96,67 & Sangat Baik \\
\hline
\end{tabular}

Berdasarkan hasil validitas yang telah disajikan pada Tabel 5, menunjukkan bahwa pengembangan media permainan edukatif tema tanaman sub tema sayur dan buah menurut ahli isi pembelajaran memperoleh persentase skor sebesar 94,23\% dengan kualifikasi sangat baik, ahli desain pembelajaran memperoleh persentase skor sebesar 92,5\% dengan kualifikasi sangat baik, ahli media pembelajaran memperoleh skor $96,67 \%$ dengan kualifikasi sangat baik, dan uji coba perorangan memperoleh skor $96,67 \%$ dengan kualifikasi sangat baik. Validitas produk media permainan edukatif tema tanaman sub tema sayur dan buah dari ahli isi pembelajaran memperoleh hasil yang sangat baik. Dalam menghasilkan atau mengembangkan sebuah media pembelajaran, tentunya materi pembelajaran pada media harus sesuai dengan kompetensi dasar, indikator, dan tujuan pembelajaran yang telah ditetapkan. Hal ini sesuai dengan teori yang dikemukakan oleh (Isdisusilo, 2012), menyatakan bahwa materi pembelajaran yang ditentukan dalam media pembelajaran atau kegiatan pembelajaran seharusnya adalah materi yang benar-benar menunjang tercapainya standar kompetensi, kompetensi dasar, indikator, dan tujuan pembelajaran. Sehingga materi pembelajaran yang tercantum pada media akan lebih cepat diterima anak dengan utuh serta dapat menarik minat anak untuk belajar lebih lanjut. Maka dari itu, sudah semestinya perlu diperhatikan kesesuaian materi yang disajikan di dalam media dengan silabus (Ganda Putri Panjaitan \& Nuzul Putri, 2020). Selain itu, media dapat berperan sebagai pengantar informasi serta untuk mengatasi kebosanan dalam belajar di kelas (Hadi, 2017; Tafonao, 2018). Berdasarkan hasil penilaian dari ahli isi pembelajaran, dapat disimpulkan bahwa media permainan edukatif tema tanaman sub tema sayur dan buah yang dikembangkan layak digunakan untuk anak kelompok B dalam kegiatan pembelajaran di TK.

Validitas produk media permainan edukatif tema tanaman sub tema sayur dan buah dari ahli desain pembelajaran memperoleh hasil yang sangat baik. Desain pembelajaran memiliki peran yang sangat penting, hal ini karena melalui desain pembelajaran yang baik akan menciptakan pembelajaran yang terarah, nyaman, menyenangkan, serta memudahkan dalam pencapaian tujuan pembelajaran. Seperti teori yang dikemukakan oleh (Zafi \& Partono, 2020), menyatakan bahwa desain pembelajaran 
adalah suatu proses yang merumuskan dan menentukan tujuan pembelajaran, metode dan teknik, strategi pembelajaran, dan media agar tujuan umum bisa tercapai, sehingga terjaminnya kualitas pembelajaran. Desain pembelajaran juga dapat diartikan sebagai kegiatan perencanaan secara sistematis berdasarkan tujuan yang akan dicapai melalui proses manual maupun berbasis teknologi agar pembelajaran berlangsung efektif (Rahmatullah, Inanna, \& Ampa, 2020). Tujuan desain pembelajaran adalah memperoleh spesifikasi media pembelajaran dalam bentuk rancangan yang telah tervalidasi (Cikarge \& Utami, 2018). Pada media permainan edukatif tema tanaman sub tema sayur dan buah yang dikembangkan ini didesain semenarik mungkin dengan menampilkan berbagai macam gambar sayur dan buah, berbagai macam warna, dan background serta instrument musik (audio) yang digunakan sesuai dengan karakteristik anak kelompok B Taman Kanak-Kanak, hal ini bertujuan untuk menarik perhatian dan minat anak kelompok B TK Widya Santhi Denpasar. Maka dari itu media permainan edukatif ini mendapatkan kriteria sangat baik dari segi desain pembelajaran karena media ini mampu menarik perhatian anak dan memotivasi anak dalam kegiatan belajar. Berdasarkan hasil penilaian dari ahli desain pembelajaran tersebut, dapat disimpulkan bahwa media permainan edukatif tema tanaman dengan sub tema sayur dan buah yang dikembangkan layak digunakan untuk anak kelompok B dalam kegiatan pembelajaran di TK.

Validitas produk media permainan edukatif tema tanaman sub tema sayur dan buah dari ahli media pembelajaran memperoleh hasil yang sangat baik, dikarenakan media permainan edukatif ini memiliki kelebihan yaitu memudahkan anak dalam belajar mengenal berbagai macam nama sayur dan buah. Peran media dalam pembelajaran di Taman Kanak-Kanak menjadi bagian terpenting mengingat bahwa perkembangan anak usia dini berada pada masa konkret (Widiawati, Karim, \& Mayangsari, 2018). Hal tersebut sepadan dengan teori yang dikemukakan oleh (Nurrita, 2018), menyatakan bahwa pemakaian media pembelajaran dapat menumbuhkan minat anak untuk belajar hal-hal baru dalam materi pembelajaran yang disampaikan oleh guru sehingga dapat dengan mudah dipahami. Selain itu dengan adanya media pembelajaran mampu mengalihkan perhatian anak untuk tidak cepat bosan atau mampu konsentrasi dalam suatu kegiatan dengan waktu yang cukup lama dibandingkan dengan tidak menggunakan media pembelajaran (Zaini \& Dewi, 2017). Media pembelajaran yang menarik dapat menjadi rangsangan bagi anak dalam proses pembelajaran. Adapun juga teori yang dikemukakan oleh (Febriani, Mulyana, \& Rahman, 2020), menyatakan bahwa melalui media permainan edukatif dapat mengajarkan anak untuk melatih konsentrasi saat memainkannya. Selain itu media permainan edukatif mampu menarik perhatian anak agar memainkan permainan tersebut yang memiliki fungsi pembelajaran, sehingga dapat menambah daya ingat anak. Berdasarkan hasil penilaian dari ahli media pembelajaran tersebut, dapat disimpulkan bahwa media permainan edukatif tema tanaman sub tema sayur dan buah yang dikembangkan layak digunakan untuk anak kelompok B dalam kegiatan pembelajaran di TK.

Validitas produk media permainan edukatif tema tanaman sub tema sayur dan buah dari uji coba produk yaitu uji coba perorangan memperoleh hasil yang sangat baik. Media permainan edukatif tema tanaman sub tema sayur dan buah yang dikembangkan ini mampu menarik perhatian anak kelompok B saat proses pembelajaran berlangsung, hal ini dikarenakan media permainan edukatif menampilkan berbagai macam gambar sayur dan buah dengan background dan instrument musik (audio) yang menarik serta terdapat empat pilihan permainan, diantaranya mengenal nama-nama sayur dan buah dengan menggunakan tiga bahasa yaitu Bahasa Indonesia, Bahasa Inggris, dan Bahasa Bali, selain itu terdapat juga pilihan permainan menebak sayur atau buah, menghitung jumlah sayur atau buah, dan puzzle sayur atau buah. Melalui media permainan edukatif ini dapat meningkatkan motivasi anak dalam kegiatan belajar, membantu anak dalam mengenalkan keaksaraan awal, menambah kosakata, dan menstimulasi perkembangan kognitif anak. Sesuai dengan teori yang dikemukakan oleh (Hairiyah \& Mukhlis, 2019), menyatakan bahwa dengan adanya media permainan edukatif tentunya proses pembelajaran akan berlangsung lebih efektif dan efisien, karena pada dasarnya dalam dunia pendidikan anak usia dini pembelajaran berlangsung sambil bermain. Hal ini sejalan dengan teori yang dikemukakan oleh (Wijanarko, Darmawanto, Permatasari, Assaadah, \& Nurjanah, 2021) yang menyatakan bahwa pada dasarnya pembelajaran pada anak usia dini adalah learning by playing yang menghendaki proses pembelajaran dilakukan melalui permainan. Artinya melalui permainan anak mampu menyerap pembelajaran dengan baik. Dalam hal ini dapat diketahui bahwa media permainan edukatif dapat memperjelas materi yang diberikan, memberikan motivasi dan merangsang anak untuk bereksplorasi dalam mengembangkan berbagai aspek perkembangannya, serta memberikan kesenangan pada anak melalui bermain.

Keunggulan dari media permainan edukatif tema tanaman sub tema sayur dan buah adalah media ini dikembangkan dengan menggunakan teknologi berbasis android, sehingga mudah diakses atau mudah dijangkau dan mudah digunakan oleh anak kapan dan dimana saja. Selain itu informasi yang diberikan kepada anak melalui media ini dapat disampaikan lebih banyak karena terdapat lima unsur diantaranya 
adanya animasi, teks, gambar sayur atau buah, suara atau musik, dan video. Dampak menggunakan media permainan edukatif ini yaitu dapat menarik perhatian anak, meningkatkan motivasi anak dalam kegiatan belajar, membantu anak dalam mengenalkan keaksaraan awal, menambah kosakata, dan menstimulasi aspek perkembangan kognitif anak. Kontribusi hasil penelitian pengembangan ini dapat digunakan atau dimanfaatkan dalam bidang pendidikan di Taman Kanak-Kanak khususnya pada pembelajaran tema tanaman sub tema sayur dan buah. Penelitian ini menghasilkan sebuah media permainan edukatif tema tanaman sub tema sayur dan buah yang dikembangkan dengan menggunakan teknologi berbasis android, sehingga media ini dapat digunakan dimana saja dan kapan saja. Melalui media permainan edukatif ini dapat menumbuhkan semangat anak kelompok B untuk bermain sambil belajar serta memberikan pengalaman belajar yang menarik dan menyenangkan sehingga terstimulasinya aspek perkembangan anak khususnya aspek kognitif dan bahasa.

Hasil penelitian ini memiliki beberapa implikasi diantaranya yaitu media permainan edukatif tema tanaman sub tema sayur dan buah yang telah dikembangkan ini memberikan kesempatan pada anak untuk mengenal berbagai macam sayur dan buah dengan cara bermain. Dalam media ini terdapat pengenalan sayur dan buah dengan menampilkan gambar-gambar sayur dan buah yang menggunakan tiga bahasa yaitu Bahasa Indonesia, Bahasa Inggris, dan Bahasa Bali. Penggunaan tiga bahasa ini bertujuan untuk mengenalkan keaksaraan awal dan menambah kosakata anak sehingga terstimulasinya aspek bahasa. Selain itu terdapat juga pilihan permainan lainnya yaitu menebak, menghitung, dan puzzle yang bertujuan untuk menstimulasi aspek perkembangan kognitif anak dan meningkatkan minat belajar anak. Secara empiris terbukti bahwa produk pengembangan media permainan edukatif tema tanaman sub tema sayur dan buah ini layak digunakan dalam proses pembelajaran di TK Widya Santhi Denpasar karena memperoleh kualifikasi sangat baik dari ahli isi pembelajaran, ahli desain pembelajaran, ahli media pembelajaran, dan uji coba perorangan. Media permainan edukatif tema tanaman sub tema sayur dan buah yang dikembangkan ini mampu menarik perhatian anak kelompok B saat proses pembelajaran berlangsung, membantu anak dalam mengenalkan keaksaraan awal, menambah kosakata, dan menstimulasi perkembangan kognitif anak, serta berpengaruh positif terhadap minat belajar anak dimasa proses pembelajaran daring seperti saat ini. Pada pengembangan ilmu, media permainan edukatif ini dapat dikembangkan untuk materi lainnya serta untuk tema pembelajaran yang lain selain tema pembelajaran tanaman sub tema sayur dan buah, serta tentunya penting untuk disesuaikan antara desain pembelajaran dengan isi pembelajarannya.

Media permainan edukatif ini juga memiliki keterbatasan pengembangan yaitu media permainan edukatif tema tanaman sub tema sayur dan buah merupakan sebuah media yang dikemas atau dikembangkan dengan menggunakan teknologi berbasis android yang hanya bisa digunakan untuk mengenal berbagai jenis sayuran dan buah-buahan, serta media ini hanya dapat dimainkan pada handphone. Bagi peneliti selanjutnya disarankan agar hasil penelitian ini dapat dijadikan sebagai acuan dasar dalam melakukan penelitian pengembangan lebih lanjut yang menggunakan teknologi seperti handphone ataupun laptop, sehingga mampu mengembangkan media permainan edukatif dengan teknologi terkini khususnya pada pembelajaran tema tanaman sub tema sayur dan buah agar menjadi lebih baik lagi.

\section{Simpulan}

Kesimpulan dari hasil penelitian yang telah dilakukan ini adalah dihasilkan sebuah media permainan edukatif tema tanaman sub tema sayur dan buah dengan menggunakan teknologi berbasis android yang ditujukan kepada anak kelompok B TK Widya Santhi Denpasar. Media permainan edukatif tema tanaman sub tema sayur dan buah ini praktis dan layak digunakan untuk anak kelompok B dalam kegiatan pembelajaran di TK Widya Santhi Denpasar.

\section{Daftar Rujukan}

Amiran, S. (2016). Efektifitas Penggunaan Metode Bermain Di PAUD Nazareth Oesapa. Jurnal Pendidikan Anak, 5(1). https://doi.org/10.21831/jpa.v5i1.12367.

Aprilianto, A., \& Mariana, W. (2018). Permainan Edukasi (Game) Sebagai Strategi Pendidikan Karakter. Nazhruna: Jurnal Pendidikan Islam, 1(1), 139-158. https://doi.org/10.31538/nzh.v1i1.47.

Ayuni Kaffah, S., Nurul Arafah, R., Lastika Rahimsyah, M., Nurfauziah Hayati, A., Bia Alpiansah, A., Ziaul Haq Iskandar, D., ... Firmansyah, R. (2020). Media Pembelajaran Multimedia Interaktif Mengenai Pengenalan Nama Buah dalam Tiga Bahasa untuk Anak Usia Dini. Indonesian Journal of Early Childhood: Jurnal Dunia Anak Usia Dini, 2(2), 2655-6561. https://doi.org/10.35473/ijec.v2i2.542.

Bujuri, D. A. (2018). Analisis Perkembangan Kognitif Anak Usia Dasar dan Implikasinya dalam Kegiatan 
Belajar Mengajar. LITERASI (Jurnal Ilmu Pendidikan), 9(1), 37-50. Retrieved from https: //www.journal.almaata.ac.id/index.php/LITERASI/article/view/720.

Cikarge, G. P., \& Utami, P. (2018). Analisis dan Desain Media Pembelajaran Praktik Teknik Digital Sesuai RPS. Elinvo (Electronics, Informatics, and Vocational Education), 3(1), 92-105. https://doi.org/10.21831/elinvo.v3i1.20509.

Erwin, V. A., \& Syukur, Y. (2019). Multimedia Interaktif Bermuatan Permainan Edukatif di Sekolah Dasar. Jurnal Basicedu, 3(3), 901-908. https://doi.org/10.31004/BASICEDU.V3I3.183.

Fadlillah, M. (2019). Buku Ajar Bermain \& Permainan Anak Usia Dini. Jakarta: PRENADAMEDIA GROUP.

Febriani, A. S., Mulyana, E. H., \& Rahman, T. (2020). Pengembangan Educative Game Berbasis Aplikasi Android untuk Memfasilitasi Keterampilan Membaca Anak Usia 5-6 Tahun. JURNAL PAUD AGAPEDIA, 2(2), 187-196. https://doi.org/10.17509/jpa.v2i2.24544.

Firmadani, F. (2020). Media Pembelajaran Berbasis Teknologi Sebagai Inovasi Pembelajaran Era Revolusi Industri 4.0. KoPeN: Konferensi Pendidikan Nasional, 2(1), 93-97. Retrieved from http://ejurnal.mercubuana-yogya.ac.id/index.php/Prosiding_KoPeN/article/view/1084.

Ganda Putri Panjaitan, R., \& Nuzul Putri, N. (2020). Multimedia Interaktif Berbasis Game Edukasi Sebagai Media Pembelajaran Materi Sistem Pernapasan di Kelas XI SMA. Jurnal Pendidikan Sains Indonesia (Indonesian Journal of Science Education), $8(1), \quad 141-151$. https://doi.org/10.24815/jpsi.v8i1.16062.

Hadi, S. (2017). Efektivitas Penggunaan Video Sebagai Media Pembelajaran untuk Siswa Sekolah Dasar. Seminar Nasional Teknologi Pembelajaran Dan Pendidikan Dasar 2017, 1(15), 96-102. Retrieved from https://core.ac.uk/download/pdf/267023793.pdf.

Hairiyah, S., \& Mukhlis. (2019). Pengembangan Kreativitas Anak Usia Dini Melalui Permainan Edukatif. Jurnal Kariman, 7(2), 265-282. https://doi.org/10.52185/kariman.v7i2.118.

Harjanta, A. T. J., \& Herlambang, B. A. (2018). Rancang Bangun Game Edukasi Pemilihan Gubernur Jateng Berbasis Android dengan Model ADDIE. Jurnal Transformatika, 16(1), 91-97. Retrieved from https://journals.usm.ac.id/index.php/transformatika/article/view/894.

Hasanah, N. (2020). Pengembangan Media Pembelajaran Puzzle 3 Dimensi Terhadap Kecerdasan Sosial Anak Usia Dini Di Kelompok B RA Baitul Islah Kota Bengkulu (Institut Agama Islam Negeri Bengkulu). Retrieved from http://repository.iainbengkulu.ac.id/id/eprint/4377.

Hayati, N., Cholimah, N., \& Christianti, M. (2017). Identifikasi Keterampilan Kognitif Anak Usia 2-6 Tahun di Lembaga PAUD Kecamatan Sleman, Yogyakarta. Jurnal Pendidikan Anak, 6(2), 181-189. https://doi.org/10.21831/jpa.v6i2.17705.

Hemah, E., Sayekti, T., \& Atikah, C. (2018). Meningkatkan Kemampuan Bahasa Anak Melalui Metode Bercerita Pada Anak Usia 5-6 Tahun. Jurnal Penelitian Dan Pengembangan Pendidikan Anak Usia Dini, 5(1), 1-14. Retrieved from http://jurnal.untirta.ac.id/index.php/jpppaud/article/view/4675.

Holis, A. (2017). Belajar Melalui Bermain untuk Pengembangan Kreativitas dan Kognitif Anak Usia Dini. In Jurnal Pendidikan UNIGA (Vol. 10). https://doi.org/10.52434/JP.V10I1.84.

Isdisusilo. (2012). Panduan Lengkap Menyusun Silabus dan Rencana Pelaksanaan Pembelajaran. Jakarta: Kata Pena.

Isya', M. A. (2017). Pengembangan model pembelajaran instruksional design dengan model Addie mata pelajaran PAI pada materi mengulang-ulang hafalan Surah Al Ma'un dan al Fil secara klasikal, kelompok dan individu kelas V SDN Gedongan 2 Kota Mojokerto. Ta'dibia: Jurnal Ilmiah Pendidikan Agama Islam, 7(1), 71. https://doi.org/10.32616/tdb.v7.1.37.71-80.

Lestari, S. Y., Hadi, H., \& Mushafanah, Q. (2019). Pengaruh Model Problem Based Learning Berbantu Permainan Edukatif Terhadap Hasil Belajar Tematik. Jurnal Sinektik, 2(1), 97. https://doi.org/10.33061/js.v2i1.2979.

Mardhotillah, I. (2019). Pengembangan Media Maze Matematika untuk Mengembangkan Kemampuan Kognitif Anak Usia 5-6 Tahun di Taman Kanak-Kanak (Unoversitas Islam Negeri Raden Intan Lampung). Retrieved from http://repository.radenintan.ac.id/6487/1/SKRIPSI LENGKAP.pdf.

Maslich, I. Y. (2016). Pengembangan Media Papan Pintar Angka (Papika) bagi Anak Kelompok A di Taman Kanak-Kanak Nasional Samirono Caturtunggal Depok Sleman Yogyakarta. E-Jurnal Skripsi Program Studi Teknologi Pendidikan, 5(6), 179-192. Retrieved from https: //www.google.com/url?sa=t\&source=web\&rct=j\&url=http://journal/student.uny.ac.id/ojs /indeks.php/fiptp/article/view/3100\&ved=2ahaUKEwjaslul5ejuAhX07nMBHRGjCCEQFjAAegQI ARAB\&usg=AOvVaw3YxZwyttGhZLhjEcyG6QXF.

Mubaraq, M. R., Kurniawan, H., \& Saleh, A. (2018). Implementation of Augmented Reality for Fruit Learning Media Android Based. In IT (Informatic Technique) Journal (Vol. 6). https://doi.org/10.22303/IT.6.1.2018.89-98. 
Norlaila, H. (2015). Upaya Pengembangan Aspek Kognitif Dalam Aktivitas yang Bersifat Eksploratif \& Menyelidik (Mencampur Warna) Menggunakan Model Example non Examples di Kelompok B TK Tunas Muda Kec. Simpang Empat Kab. Banjar. JEA, 1(1), 66-95. Retrieved from http://jurnal.uinantasari.ac.id/index.php/jurnalaud/article/view/2147.

Nurhayati, H. (2015). Pengembangan Alat Permainan Edukatif Rumah Kata untuk Anak TK Kelompok B. Jurnal Teknologi Pendidikan, 6(3), 1-13. Retrieved from http://journal.student.uny.ac.id/ojs/index.php/fiptp/article/view/713/0.

Nurrita, T. (2018). Pengembangan Media Pembelajaran untuk Meningkatkan Hasil Belajar Siswa (Vol. 03).

Putra, R. C. (2016). Pembuatan Game Edukasi Pintar Memilih Sampah Berbasis Android Publikasi Ilmiah (Universitas Muhammadiah Surakarta). $\quad$ Retrieved from https: //core.ac.uk/download/pdf/148612565.pdf.

Rahman, R. A., \& Tresnawati, D. (2016). Pengembangan Game Edukasi Pengenalan Nama Hewan dan Habitatnya dalam 3 Bahasa Sebagai Media Pembelajaran Berbasis Multimedia. Jurnal Algoritma Sekolah Tinggi Teknologi Garut, 13(1), 184-190. Retrieved from http://www.sttgarut.ac.id/jurnal/index.php/algoritma/article/view/323.

Rahmatullah, Inanna, \& Ampa, A. T. (2020). Media Pembelajaran Audio Visual Berbasis Aplikasi Canva. Jurnal Pendidikan Ekonomi Undiksha, 12(2), 317-327. Retrieved from www.canva.com.

Ramdani, M. D., Kurniadi, D., \& Septiana, Y. (2019). Rancang Bangun Game Edukasi Penelusuran Goa Berbasis Android. Jurnal Algoritma, 16(2), 151-157. https://doi.org/10.33364/algoritma/v.162.151.

Rohaeni, S. (2020). Pengembangan Sistem Pembelajaran dalam Implementasi Kurikulum 2013 Menggunakan Model ADDIE Pada Anak Usia Dini. Instruksional, 1(2). Retrieved from https://jurnal.umj.ac.id/index.php/instruksional/article/view/6258.

Saputra, A. (2019). Permainan Edukatif untuk Anak Usia Dini. PELANGI: Jurnal Pemikiran Dan Penelitian Islam Anak Usia Dini, 1(1), 102-113. https://doi.org/10.52266/pelangi.v1i1.283.

Satria, M., \& Rusda, D. (2017). Aplikasi Game Edukasi Pengenalan Alphabet Untuk Anak Usia 3 Hingga 5 Tahun Berbasis Android. In Jurnal Penelitian Dosen FIKOM (UNDA) (Vol. 4). Retrieved from http://jurnal.unda.ac.id/index.php/Jpdf/article/view/37.

Soesilo, A., \& Munthe, A. P. (2020). Pengembangan Buku Teks Matematika Kelas 8 Dengan Model ADDIE. Scholaria: Jurnal Pendidikan Dan Kebudayaan, 10(3), 231-243. https: //doi.org/10.24246/j.js.2020.v10.i3.p231-243.

Sudiatmika, I. D. P. A., Cahyawan, A. A. K. A., \& Buana, P. W. (2014). Aplikasi Game Edukasi Trash Grabber Untuk Mengenal Jenis-Jenis Sampah Pada Smartphone Berbasis Android. Merpati, 2(2), 215-225. Retrieved from http://ocs.unud.ac.id/index.php/merpati/article/view/17889.

Sugiyono. (2015). Metode Penelitian Pendidikan Pendekatan Kuantitatif, Kualitatif dan RnD. Bandung: Alfabeta.

Tafonao, T. (2018). Peranan Media Pembelajaran Dalam Meningkatkan Minat Belajar Mahasiswa. Jurnal Komunikasi Pendidikan, 2(2), 103-114. Retrieved from http://journal.univetbantara.ac.id/index.php/komdik/article/view/113.

Widiawati, W. W., Karim, M. B., \& Mayangsari, D. (2018). Pengaruh Media Pembelajaran Berbasis Komputer Aplikasi Paint Terhadap Kemampuan Kognitif Anak Usia 4-5 Tahun di TK Aisyiyah Bustanul Athfal 22 Balongpanggang. Jurnal PG-PAUD Trunojoyo: Jurnal Pendidikan Dan Pembelajaran Anak Usia Dini, 5(1), 10-24. https://doi.org/10.21107/pgpaudtrunojoyo.v5i1.3845.

Wijanarko, K. D., Darmawanto, E., Permatasari, S., Assaadah, N. M., \& Nurjanah, F. A. (2021). Pemanfaatan Kain Flanel Sebagai Alat Pembelajaran Edukatif Busy Book Di TK TA 03 Jerukwangi. 1(2), 148-155. Retrieved from http://jurnal.atidewantara.ac.id/index.php/singkerru/article/view/74.

Zafi, A. A., \& Partono, P. (2020). Desain Pembelajaran sebagai Upaya Peningkatan Kualitas Pembelajaran al-Quran Hadis. Matan: Journal of Islam and Muslim Society, 2(1), 16. https: //doi.org/10.20884/1.matan.2020.2.1.2292.

Zaini, H., \& Dewi, K. (2017). Pentingnya Media Pembelajaran untuk Anak Usia Dini. Raudhatul Athfal: Jurnal Pendidikan Islam Anak Usia Dini, 1(1), 81-96. https://doi.org/10.19109/ra.v1i1.1489. 